\begin{tabular}{|l|l|}
\hline & \\
\hline &
\end{tabular}

SEÇÃO LIVRE

\title{
Tradição e modernismo na construção da "nova" mulher do Estado Novo português: fotografia e propaganda no Boletim da Mocidade Portuguesa Feminina (1939-1947) ${ }^{1}$
}

Tradition and Modernism in the construction of the "new" woman from the Portuguese New State: photography and propaganda in the Boletim da Mocidade Portuguesa Feminina (1939-1947)

Tradición y Modernismo en la construcción de la "nueva" mujer del "Estado Novo" portugués: fotografia y propaganda en el Boletim da Mocidade Portuguesa Feminina (1939-1947)

\section{Bruno Sousa Marques ${ }^{2}$ \\ 0000-0001-9693-0090}

brunosousamarques@gmail.com

\section{Israel Vindeirinho}

\section{Guarda}

0000-0001-8139-4977 quarda.israel@gmail.com

Recebido em: 30 out. 2018. Aprovado em: 17 abr. 2019. Publicado em: 25 ago. 2020.

\section{(c) (1)}

Artigo está licenciado sob forma de uma licença Creative Commons Atribuição 4.0 Internacional.
Resumo: As imagens que constroem o ideal de "nova" mulher do Estado Novo Português estabelecem um importante guia para compreender a forma heterodoxa e "contraditória" como foi usada a fotografia enquanto meio de inculcação de um modelo feminino consentâneo com a ideologia do regime. Estas revelam uma intrinseca dialética entre conteúdos/ formas "tradicionalistas" e "modernistas". Tomando como objecto de análise as fotografias publicadas no Boletim da Mocidade Portuguesa Feminina (1939-1947), o presente artigo visa compreender de que modo esta dialética é deliberadamente posta ao serviço da propaganda do Estado Novo.

Palavras-chave: Boletim da Mocidade Portuguesa Feminina. Propaganda. Fotografia impressa. Estado Novo. Mulher "nova".

Abstract: The images that outlined the "new" women ideal of the Portuguese New State government (Estado Novo), set an important guide to understand how the photography was used to establish a female role model consentaneous with the regime ideology. At first glance these images appear odd and contradictory, but a closer look one can identify an intrinsic dialectic between "tradition" and "modernist" themes and forms. Taking as case study the Boletim de Mocidade Portuguesa Feminina (Portuguese Women's Youth Bulletin) (1939-1947), the aim of this work is to analyze how this dialectic was operated at the service of the New State propaganda.

Keywords: Female Portuguese Youth bulletin. Propaganda. Printed photography. New State. "New" women.

Resumen: Las imágenes que construyen el ideal de la "nueva" mujer del Estado Novo portugués, establecen una guía importante para entender cómo se utilizó la fotografía como medio de inculcación de un modelo femenino de acuerdo con la ideología del régimen. Estas revelan una intrínseca dialéctica entre temas / formas "tradicionalistas" y "modernistas". Tomando como tema las fotos publicadas en el Boletim de la Mocidade Portuguesa Feminina (1939-1947), el objetivo de este artículo es entender cómo esta dialéctica se lleva a cabo al servicio de la propaganda del Estado Novo.

Palabras clave: Boleta de las mujeres Jóvenes Portugueses. Propaganda. Fotografia impresa. Estado Nuevo. "Nueva" mujer.

\footnotetext{
1 Este trabalho é financiado por fundos nacionais através da FCT - Fundação para a Ciência e a Tecnologia, I.P., no âmbito da celebração do contrato-programa previsto nos números 4, 5 e 6 do art. 23. do D.L. n. ${ }^{\circ}$ 57/2016, de 29 de agosto, alterado pela Lei n. ${ }^{\circ} 57 / 2017$, de 19 de julho." e foi desenvolvido no âmbito do Projecto FCT "Fotografia Impressa. Imagem e Propaganda em Portugal (1934-1974)" [PTDC/CPC-HAT/4533/2014], tendo contado com a colaboração da estagiária Daniela Silva no âmbito do levantamento iconográfico e documental. 2 Universidade NOVA de Lisboa (NOVA), Faculdade de Ciências Sociais e Humanas, Instituto de História da Arte, Lisboa, Portugal
} 
"O Estado Novo representa o acordo e a sintese de tudo o que é permanente e de tudo o que é novo, das tradições vivas da Pátria e dos seus impulsos mais avançados".3

\section{Introdução}

A propaganda oficial do Estado Novo português fez uso no campo da fotografia de linguagens estilísticas antagónicas. Tal permitiu uma relação dialéctica entre um impulso modernista e a preservação de valores tradicionalistas e ruralistas que o regime acolheu e instrumentalizou segundo os cânones estéticos mais convenientes ao seu pragmatismo. No caso da construção do ideal de "nova" mulher, não obstante a coexistência desses elementos "tradicionalistas" e "modernistas" teima em persistir ainda na historiografia uma forte propensão para colocar a mulher exclusivamente do lado conservador e religioso do regime (COVA; PINTO, 1997; FREIRE, 2010; MASCARENHAS, 2001; PIMENTEL, 2011). Tal facto tem conduzido a uma imagem reducionista sobre o seu papel no interior do mesmo. Embora essa fosse a retórica dominante nos discursos oficiais, as fotografias e determinadas práticas sociais apontam para um campo repleto de contradições.

De acordo com Marie-Anne Matard-Bonucci (2004), foi no debate em torno do totalitarismo que a noção de "homem novo" adquiriu múltiplas formas. O assunto não é menor em virtude de tal objectivo ser comum a todos os regimes fascistas e autoritários que, nos anos trinta, utilizaram as noções de "ressurgimento nacional" para se demarcarem da "decadência" causada pelo demo-liberalismo. É neste quadro que se situa a estrita congruência entre o ideário de "regeneração" nacional e a atitude conservadora e religiosa do Estado Novo contrária às correntes pedagógicas liberais de matriz laica e progressista. Essa é, fundamentalmente, a razão que leva também Fernando Rosas a argumentar que, "esse 'homem novo' da propaganda, da 'educação nacional' e da 'cultura popular' era, apesar de tudo, um 'homem velho', não o da mobilização revolucionária, mas o da ordem contra-revolucionária e conservadora" (ROSAS, 2001, p. 1053).

Não sendo um objecto de estudo inexplorado, as imagens que constroem o ideal de mulher ainda não beneficiaram da atenção e da análise crítica que merecem. Os trabalhos pioneiros de Isabel Ferreira (1994) e de Irene Pimentel (1996, 2000) sobre as organizações femininas do regime permitiram já balizar historicamente esse território - ao cruzar os Estudos de Género com a História das Ditaduras -, mas falta ainda uma visão mais estritamente ancorada na linha dos Estudos de fotografia e das publicações periódicas (FERNÁNDEZ, 2000; SCHOLES, 2010; SERRA, 2017), que nos permita compreender melhor o papel da fotografia impressa ao serviço da ditadura.

Partindo do Boletim da Mocidade Portuguesa Feminina (1939-1947), o presente artigo analisa diversos motivos e tipologias de imagens que veiculam a ideia de "nova mulher" com o propósito de compreender a dialéctica entre conteúdos/ formas "tradicionalistas" e "modernistas", num momento em que a fotografia impressa atinge o seu esplendor como poderosa arma inovadora ao serviço da propaganda política.

\section{Modernismo, Fascismo e a "invenção da tradição"}

O acordo entre as "tradições vivas da Pátria" e os "seus impulsos mais avançados" - que o Decálogo do Estado Novo citado em epígrafe exalta -, encontra na capa de Janeiro de 1941 do Boletim da Mocidade Portuguesa Feminina (Figura 1) um dos seus mais perfeitos exemplos. Resultante da reportagem sobre a bênção ao Cruzeiro da Mocidade ${ }^{4}$, feita no Cabo da Roca numa "luminosa" manhã de Dezembro de 1940, a fotografia de Mário Novais (1899-1967)5 afigura-se como paradigmática da interdependência entre tradição e modernismo preconizada pelos regimes autoritários europeus do século XX. 
Figura 1 - Fotografia de capa de Mário Novais em jan. 1941

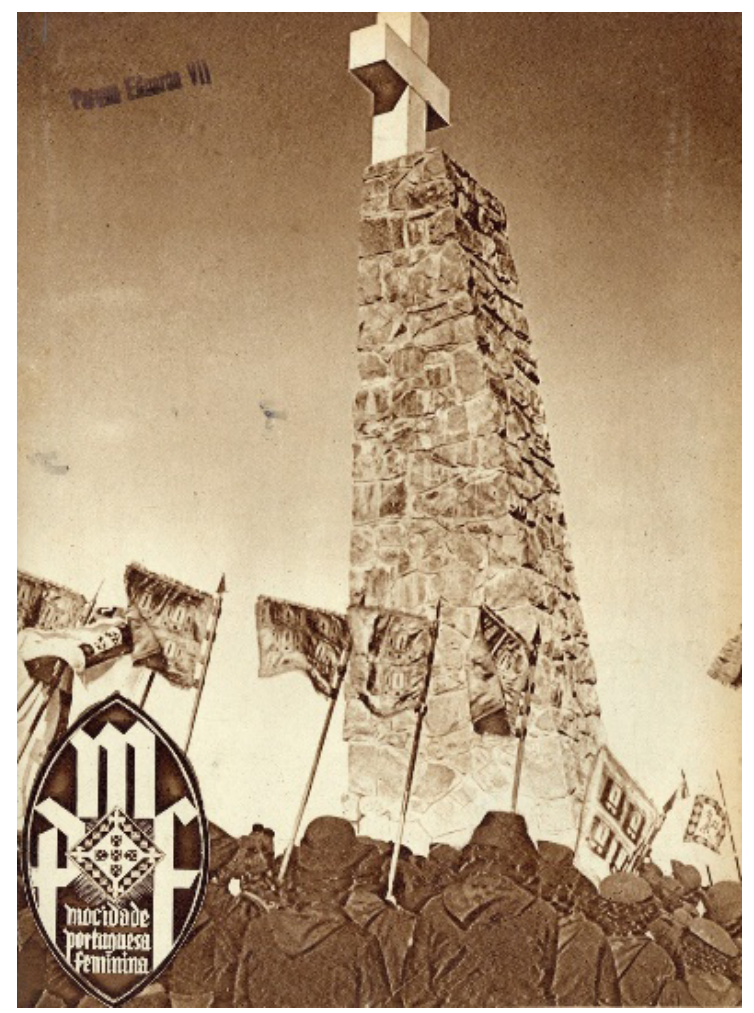

Fonte: Novais, Mário. Capa [fotografia impressa]. Boletim da Mocidade Portuguesa Feminina, n. 21 (Jan. 1941).

Ao alto, a cruz branca imponente, acima de tudo e de todos. Em baixo, "a instável vertigem guerreira de um alinhamento de estandartes" (POMAR, 1998). Enquadramento claro da imagem e representação exacta do assunto; sentido composicional e atenção dada às estruturas e às formas; contenção psicológica e ausência de estilizações pictóricas. São estas algumas das premissas fundamentais de uma tendência que identifica a fotografia como o meio privilegiado para realizar uma mudança simultaneamente artística e perceptiva: um novo tipo de imagem congruente com um momento histórico de afirmação de um Estado que se quer "Novo".

A fotografia procura assim responder esteticamente à pressão fascizante ${ }^{6}$ que, desde 1936 , se fazia sentir a partir do próprio regime, com a instrumentalização de alguns aspectos positivos (considerados não degenerativos) do modernismo, tais como as novas tecnologias da imagem, a actualidade da foto-reportagem no contexto dos periódicos e o apelo às massas. Deste modo, a encenação propagandística de cunho modernista encontra-se claramente ao serviço da tradição e dos valores católicos, tidos como elementos fundacionais do Estado Novo. Numa convergência simbólica de temporalidades, ela celebra uma espécie de "enlace" entre tradição e modernidade que se pretende exortar também em discurso imagético, agora levado a cabo mediante uma ousadia estético-formal ante temas tão históricos e fundadores como são os da Fé cristã e da Nação.

É à luz desta ambivalente rede de narrativas teleológicas - que pretendem acordar o "permanente" com o "novo" - que se compreende que Alexandre Pomar (2008) classifique estilisticamente esta fotografia como um "modernismo involutivo [...] ao mesmo tempo renovador (anti-académico) e conservador". Com efeito, tanto a imagem como as palavras do crítico de arte tornam evidente que modernismo e fascismo durante tanto tempo tidos como inconciliáveis (BARRON, 1991; ANTLIFF, 2002) - acabam por formar uma aliança comum, consubstanciando um putativo oximorón dialéctico que, entretanto, tem conhecido várias designações: "modernismo reaccionário" (HERF, 1984), "modernismo fascista" ou "modernidade totalitária" (GENTILE, 2004). Seguindo a mesma lógica dialética, esta combinação de termos contraditórios ou incongruentes toma designações mais amenizadas no contexto português: "modernismo academizante" (FRANÇA, 1974), "modernismo contido" ou "vigiado" (TAVARES, 2009), "modernismo domesticado" (LEAL; SANTOS, 2016), "heterogeneidade homogeneizada" (BRITES, 2017, p. 101), "classicização da vanguarda" ou "modernidade branda" (TRINDADE, 2017).7

\footnotetext{
6 Sob as influências radicais e fascizantes recebidas da guerra civil de Espanha e do triunfal ascenso do fascismo e do hitlerismo na Europa, em Portugal este processo "fascizante" deu-se menos ao nivel da dogmática dos conteúdos, sendo mais evidente no tocante à "coreografia" e aos instrumentos que acompanham o seu enunciado (ROSAS, 2001, p. 1033).

Esta "mistura" específica entre estética e política oficial, nomeadamente entre a "fisionomia mais tradicionalista" do autoritarismo político do regime salazarista e o movimento modernista, foi abordada nos campos da literatura (CABRAL, 1984/2014; TRINDADE, 2008), da arquitectura (ANDRÉ, 2010; BRITES, 2017), da estatuária (ACCIAIUOLI, 2013), ao qual não está alheio o mito de "Homem Novo" (ROSAS, 2001; SERRA, 2012; TESSADORI, 2014).
} 
Na introdução ao já canónico livro The Invention of Tradition que coedita com T. O. Ranger, E. J. Hobsbawm argumenta que muitas "tradições" que "aparentam ou se assumem como antigas são frequentemente muito recentes na sua origem e às vezes inventadas" (HOBSBAWM; RANGER, 1983, p. 1). ${ }^{8}$ Este historiador identifica três razões principais que o motivam: a promoção da coesão social entre comunidades artificiais, a legitimação da autoridade e a inculcação de crenças numa determinada sociedade. Segundo Hobsbawm, as "tradições inventadas" são frequentemente usadas pelas elites para manipular os cidadãos destituidos de poder, mas também servem a um conjunto diverso de instituições a fim de preservar a unidade social e evitar que estas se desmoronem face aos desafios inerentes às rápidas mutações sociais. O fenómeno torna-se particularmente evidente no caso do desenvolvimento do nacionalismo moderno. No capítulo "Mass-Producing Traditions" do mesmo livro, Hobsbawm sustenta que muitas tradições foram criadas na Europa com o objectivo de promover um sentido de unidade nacional em resposta ao declínio de outras instituições sociais unificadoras, tais como a Igreja ou as afiliações regionais, resultante das dramáticas mutações sociais que ocorrem no final do século XIX.

Mais recentemente, um autor que providencia um novo paradigma conceptual no que concerne à articulação que os fascismos estabeleceram entre modernidade e tradição é Roger Griffin (2007). Em Modernism and Fascism: The Sense of a Beginning under Mussolini and Hitler, o historiador advoga que o fascismo é uma forma ou variante do modernismo, refutando aqueles que comummente o qualificam como um fenómeno anti-moderno ou reacionário. Griffin propõe a ideia de complementaridade entre os dois atendendo ao facto dos modernistas se terem envolvido em projetos ultranacionalistas de renovação de direita, enquanto movimento de revitalização e transição para uma nova ordemª; sendo essa transição feita não a partir do zero, mas mediante a criação de utopia(s) que emergem de alguns elementos escolhidos do passado considerados apropriados e apoteóticos, e rejeitando outros tidos como decadentes e degenerados (destruição criativa). Nesta prespectiva se compreende que a tradição funcione aqui menos como um refreio ao modernismo, constituindo antes uma parte intrínseca da sua engrenagem, ${ }^{10}$ acabando por ser usada habilmente pelos Estados autoritários para fortalecer a legitimação da sua autoridade e inculcar os valores da nova sociedade a construir.

Neste âmbito, um dos contributos mais fundamentais de Roger Griffin passa também pela superação da lógica binária e da contradição entre opostos, não raras vezes usada para caracterizar os regimes fascistas e autoritários na sua articulação com o modernismo. Num artigo publicado em 2008 , o autor atenta persuadir os historiadores culturais e políticos a tratar o fascismo não como um "oxímoro a ser resolvido ou uma aberração a ser explicada, mas como uma variante completa e internamente consistente do modernismo programático". Ao fazê-lo, Griffin visa contrariar a persistente relutância em reconhecer no fascismo "um impulso sustentado para uma modernidade alternativa e para uma futuridade revolucionária" (GRIFFIN, 2008, p. 12).

É partindo desta perspectiva que, mais recentemente, Joana Brites também apresenta um posicionamento marcadamente revisionista sobre a relação que o regime de Salazar estabelece com o próprio conceito de modernismo.

Consequently, I subscribe to the short yet embracing definition of lain Boyd Whyte, for whom "modernism in architecture, as in all arts, exists only as a response to the contradictory conditions of modernity. [...] However, like other fascist regimes, the Portuguese dictatorship did not intend to tread the path back to the past. Indeed, the rescue of the homeland historical legacy, exorcised of its 'unhealthy' episodes, was intended to act as a spiritual substrate to face the mission of national regeneration to be

\footnotetext{
8 Hobsbawm define o conceito de "tradição inventada" enquanto "a set of practices, normally governed by overtly or tacitly accepted rules and of a ritual or symbolic nature, which seek to inculcate certain values and norms of behaviour by repetition, which automatically implies continuity with the past" (HOBSBAWM 1983, p. 1-2).

9 Grande parte da arte - seja ela esteticamente modernista ou não - que se aliou ao fascismo foi cunhada por Griffin de "modernismo programático", que, nas suas palavras, consubstancia 'the mission to change society, to inaugurate a new epoch, to start time anew'.

10 Tal como Dell Upton nota, "the adjectives traditional and modern are themselves artefacts of modernity: tradition did not exist until it was imagined as the defining complement of modernity" (UPTON, 2001, p. 298 apud BRITES, 2015, nota 31).
} 
undertaken in the present. [...] The Estado Novo (the very name is palingenetic) devised and applied with relative success a comprehensive project of intervention in Portuguese society. [...]. The totalising vocation of the project was expressed in the size of the apparatus created for mobilising and inculcating its ideology, so that of a "new man". Far from being reduced to a simply reactionary phenomenon, Salazarism was a political form of modernism (BRITES, [2015]).

Se considerarmos que o fascismo é uma forma de modernismo, então o oximoro "fascismo modernista" (com todas as suas variantes) perde $a$ sua razão de ser, tornando-se logo em si mesmo numa redundância de termos, a partir do momento em que aceitamos a possibilidade do primeiro poder ser encarado como uma forma alternativa do segundo e não o seu oposto ou negação. Este posicionamento compagina-se com a "intensa revisão crítica" (LEAL, 2015) que tem vindo a desconstruir o cânone do modernismo hegemónico anglosaxónico - tido como internacionalista, hierárquico, exclusivista, purista e assente sobretudo na inovação formal (GREENBERG, 1960, p. 754-755) -, que, desde os anos 1920 e 1930, pretendeu expulsar dos seus discursos de auto-legitimação todas as outras variantes possiveis - hibridas, periféricas, regionalistas, nacionalistas, programáticas, totalitárias, tradicionalistas ou vernaculares (LEFAIVRE; TZONIS, 2003; MITTER, 2008; BRITES, 2015, 2017) - da meta-narrativa que o definia enquanto circuito fechado, essencialista e auto-reflexivo (CALINESCU, 1986, p. 118-119; KRAUSS, 1974, p. 63-64; DE DUVE, 1996, p. 94).

\section{A fotografia e as publicações periódicas: uma relação recíproca}

No contexto dos anos 1920 e 1930, com os contributos inovadores das revistas Vu (19281940), Lilliput (1937-1960), Picture Post (1938-1957) e, sobretudo, com a refundação da revista Life (1936-2000), a foto-reportagem será responsável pela assimilação da imagem ao "conceito de verdade, de testemunho credivel e autêntico" (TAVARES, 2001, p. 15). Em função da sua condição de técnica, testemunho e arte, a fotografia torna-se capital na orgânica dos meios de comunicação de massas modernos, desenvolvendo, nesse dominio, uma singular aptidão como instrumento de batalhas ideológicas. Tal facto explica a sua exploração nas grandes exposições e representações internacionais como eficaz instrumento de propaganda política. Porém, será nas publicações periódicas que a fotografia conhece um incremento mais expressivo, principalmente no modo como se testou, discutiu e reproduziu nela uma 'história do instantâneo' (BELKNAP, 2016).

Será então em virtude da intersecção de três aspectos decisivos - (1) testemunho documental implicado na sua condição tecnológica (PINTO, 2015. p. 36); (2) objecto de circulação massificada entretanto intensificada pelo uso de novos processos tipográficos e de impressão que the conferem uma visibilidade sem precedentes (FERNÁNDEZ, 2000); e (3) a nova capacidade da imagem em reformular o conteúdo textual e o conceito de narrativa (TAVARES, 2009; ACCIAIUOLI, 2013; PINTO, 2015) com o nascimento da foto-reportagem de cariz actual e moderno (TAVARES, 2010) - que a fotografia encontrará, sob o controlo de diferentes regimes politicos, novas formas de aplicação em matéria de informação e manipulação da opinião pública num ambiente de politização e nacionalismo crescente.

Em Portugal, já desde o início do século XX, com a instauração da República, a imagem fotográfica vinha sendo sujeita aos postulados de propaganda política. Porém, esta seria apenas particularmente organizada e estruturada a partir do Estado Novo (TAVARES, 2010; ACCIAIUOLI, 2013), momento que faz da fotografia um directo veículo de inculcação ideológica. Sob a acção da designada "Política do Espírito", tal como proposta e desenvolvida pelo influente director do Secretariado da Propaganda Nacional (SPN), António Ferro (1895-1956), as imagens de propaganda estavam então em movimento permanente: surgiam não só em exposições oficiais ${ }^{11}$, mas também se difundiam em álbuns, brochuras, livros, cartazes, documentários, revistas ilustradas etc. Não obstante, existe uma clara noção a respeito do potencial de propaganda sobretudo ao nivel das publicações periódicas que,

11 Sobre as exposições do Estado Novo veja-se Acciaiuoli (1998) e Paulo (1996). 
por comparação com outras publicações, eventos e/ou exposições, apresentava uma clara vantagem de continuidade no tempo, e, por conseguinte, uma regularidade que permitia pôr em processo mecanismos mais sofisticados e sedimentados de inculcação ideológica.

Com efeito, a criação de publicações periódicas de natureza estatal conhece um vigoroso incremento neste período de consolidação do Estado Novo. Estas serviram, complementarmente, como importantes veículos de informação das políticas e das actividades de diferentes sectores do regime. Entre outras, há que mencionar o Noticias Ilustrado (19281935), que embora não directamente dependente de um órgão do Estado, servirá como importante trampolim para a criação de uma imagem consentânea com o novo regime, como sucede com o álbum Portugal 1934, ambos sob a direcção de Leitão de Barros (1896-1967). E, de entre aqueles reconhecidamente ligados ao regime, contam-se - Bandarra Semanário da Vida Portuguesa (Mar. 1935 - Jan. 1936), financiado unicamente pelo SPN e onde António Ferro testará activamente a sua política de espírito, funcionando como prólogo da principal publicação periódica da propaganda estadonovista: Panorama Revista Portuguesa de Arte e Turismo (1941-1973); por sua vez, o Jornal da Mocidade Portuguesa, dirigido aos jovens desta estrutura paramilitar, estabelecia as bases de formação da futura escol do regime (Dez. 1937 - Set. 1940), seria retomada em 1942, com conteúdos mais lúdicos e menos politizados; ou, o Boletim da Agência das Colónias, criado originalmente em 1924. com nova série a partir de 1933 (até 1951), ${ }^{12}$ tornando-se num valioso repositório de ciência colonial, segundo José Garcia (2016). Esta enumeração não exaustiva serve para destacar, a par das exposições e da edição de catálogos, álbuns e outros meios de comunicação, o quanto o regime tirou o melhor partido destes dispositivos para firmar e consolidar as suas posições na sociedade portuguesa.
É neste contexto que surge também o Boletim da Mocidade Portuguesa Feminina, publicação que, como o nome indica, se dirigia às suas filiadas, num momento em que aquela organização (MPF.) - criada em 1937 pelo Ministro da Educação Nacional, Carneiro Pacheco (1887-1957), e tutelada pelo Ministério da Educação Nacional ${ }^{13}$-, se propunha enquadrar toda a juventude feminina. Com uma periodicidade mensal, o Boletim da MPF acompanhou esta organização no periodo entre maio de 1939 e abril de 1947, contando na totalidade com 96 números ${ }^{14}$.

Tendo como editora Maria Joana Mendes Leal (1896-1976) - católica convicta e, desde 1937, vogal da direcção da Obra das Mães pela Educação Nacional (1937) - o Boletim dirigiu-se sobretudo às estudantes das classes sociais mais altas, a partir das quais se tentou formar um escol feminino colaborador da elite masculina do Estado Novo, para assim criar uma "nova" mulher (KUIN, 1996).

\section{Educação moral e religiosa}

Um périplo pelo Boletim da MPF dos primeiros anos de publicação permite acompanhar o desígnio de moldar as leitoras através de imagens que veiculam os ideais da doutrina católica. Importa, desde logo, destacar a glorificação de modelos históricos e religiosos, tais como a realeza e a santidade - correlato de pureza - associados à conduta da mulher-tipo da MPF. Não por acaso, a capa do primeiro número do Boletim (lançado na data simbólica de 13 de maio de 1939) reproduz, em corpo inteiro, o monumento à Rainha D. Leonor, a padroeira da Mocidade Portuguesa Feminina, executado por Francisco Franco (1885-1955), o grande escultor do regime. A misericórdia e a piedade como valores imanentes, aqui personificados na figura escultórica, encontram particular expressão nas mãos que seguram o rosário sobre o ventre. Imagens como esta cumprem a função

\footnotetext{
12 A partir de agosto de 1951, no contexto da autodeterminação das antigas posses territoriais ligadas a vários países europeus, o título altera-se para Boletim Geral do Ultramar (1951-1970).

13 A direção e organização da MPF cabia à Obra das Mães para a Educação Nacional (OMEN), que delegava a chefia num comissariado nacional à sua escolha, constituído, em 1938, por Maria Guardiola (comissária nacional), Luisa Vanzeller e Fernanda d'Orey (comissárias adjuntas). Só em 1951 a MPF se autonomizará da OMEN

${ }_{14}$ A partir desta data passa a designar-se de Menina e Moça. Ao contrário do Boletim MFP cuja formação coincide com a criação da estrutura da organização e na formação da futura elite dirigente, aquela surge num periodo em que se procura atingir um número maior de jovens mulheres (PIMENTEL, 2007).
} 
de catecismo para o "resgate das almas", tendo como missão essencial a de reconduzir as jovens portuguesas a uma "nova ordem moral". Em nome da "recristianização de Portugal", vários são os exemplos do modo como as filiadas deveriam assumir uma atitude devocional - capas do n. ${ }^{\circ}$ 12 (Abril 1940) e n. ${ }^{\circ} 32$ (Dez. 1941) -, e de compenetrada oração - n. ${ }^{\circ} 28$ (Agosto 1941, "4. ${ }^{\circ}$ Novas").

No que concerne aos cânones estéticos da linguagem fotográfica, explora-se recorrentemente um efeito pictural de diluição do real. Aqui a força do pitoresco é assumida pelo fotógrafo com nuances e exercícios de estilo, eximindo-se ao registo documental. Veja-se a este título a capa do $n^{\circ} 32$ (Dez. 1941), uma encenação replicada no n. ${ }^{\circ} 44$ (Dez. 1942), no qual vemos cinco jovens contemplando o menino Jesus num modesto berço de palha (Figura 2). Os efeitos da iluminação nocturna e o dramático claro-escuro, historicamente associado ao tenebrismo barroco, resulta aqui sintomático da validação estética fotográfica sob modelos pictóricos, que tinham durante o século XIX servido frequentemente de termo de comparação e teimavam em prevalecer (ACCIAIUOLI, 2013).

Figura 2 - Fotografia de capa de San-Payo

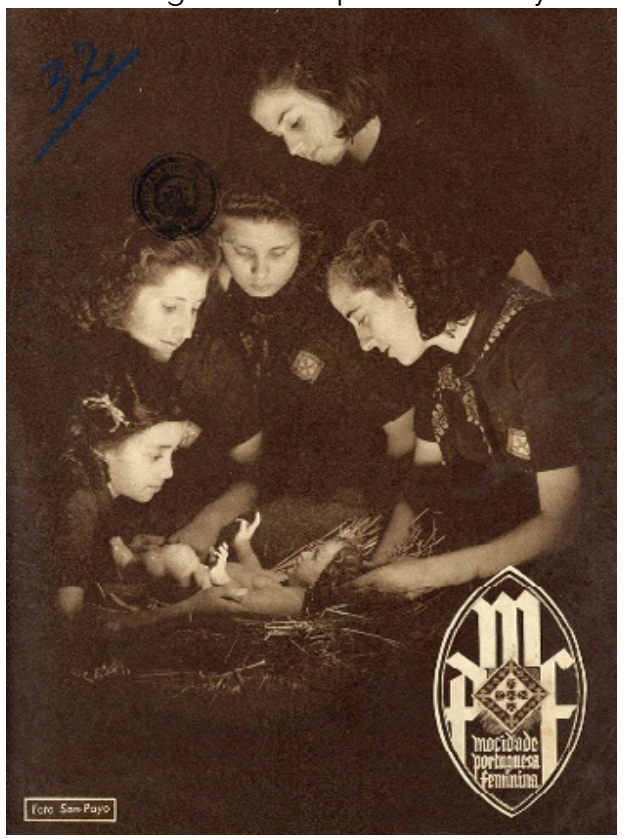

Fonte: San Payo. Capa [fotografia impressa]. Boletim da Mocidade Portuguesa Feminina, n. ${ }^{\circ} 32$ (Dez. 1941).

\section{Formação nacionalista}

Uma das imagens mais icónicas do Boletim é o sorriso exaltante, ostensivo, vendendo a imagem da MPFcomo um lugar de bem-estar, agenciador de actividades simultaneamente lúdicas e sãs, n. 5 (Set. 1939 - "Colónias de férias da MPF do Estoril"). Uma série de retratos individualizados enquadram as filiadas no seu meio, ensaiando captações de alma num retrato lato do social, como se verifica na capa do n. ${ }^{\circ} 49$ (Maio 1943) ${ }^{15}$. Por vezes, grandes planos contrapicados conferem alguma monumentalidade - capas dos números 4 (Ago. 1939), (Figura 3) e 11 (Mar. 1940) -, reenquadrados a fim de realçar a expressividade do rosto.

Se é recorrente o registo da presença da MPF nas homenagens públicas a Salazar e nas cerimónias presididas por altos representantes da Igreja n. 26 (Jun. 1941 - "Vida da Mocidade") ou no n. ${ }^{\circ} 11$ (Mar. 1940, "A benção da sede da MPF"), noutras não existe qualquer evento público que justifique a situação encenada, estando simplesmente o grupo em pose para a objectiva, n. ${ }^{\circ} 54$ (Out. 1943, capa). Nestas últimas, o aparato formal e compositivo é, por norma, mais elaborado, sobretudo quando se exploram jogos entre diagonais e verticais que se replicam e entrecruzam. São várias as imagens que respeitam esta matriz. Elas aparecem fardadas, rigidamente em fila, com saudação romana e exibindo o S (de Salazar) obrigatório no cinto, atestando o culto da personalidade do chefe ${ }^{16}$, n. $^{\circ} 3$ (Jul. 1939, capa); hasteando bandeiras com símbolos nacionalistas, n. ${ }^{\circ} 14$ (Jun. 1940, "MFP e as Comemorações Centenárias"); e adoptando postura firme e semblante levantado, n. ${ }^{\circ} 25$ (Maio 1941, capa).

15 Ver também as capas dos números 14 (Jun. 1940) e 38 (Jun. 1942).

16 Ver igualmente os números 18 (Out. 1940, artigo "Dr. Carneiro Pacheco"); n. 49 (Maio 1943, "Notícias da M.P.F.") e n. 50 (Jun. 1943. artigo "Campismo") 
Figura 3 - Fotografia de capa de Mário Novais em Agosto 1939

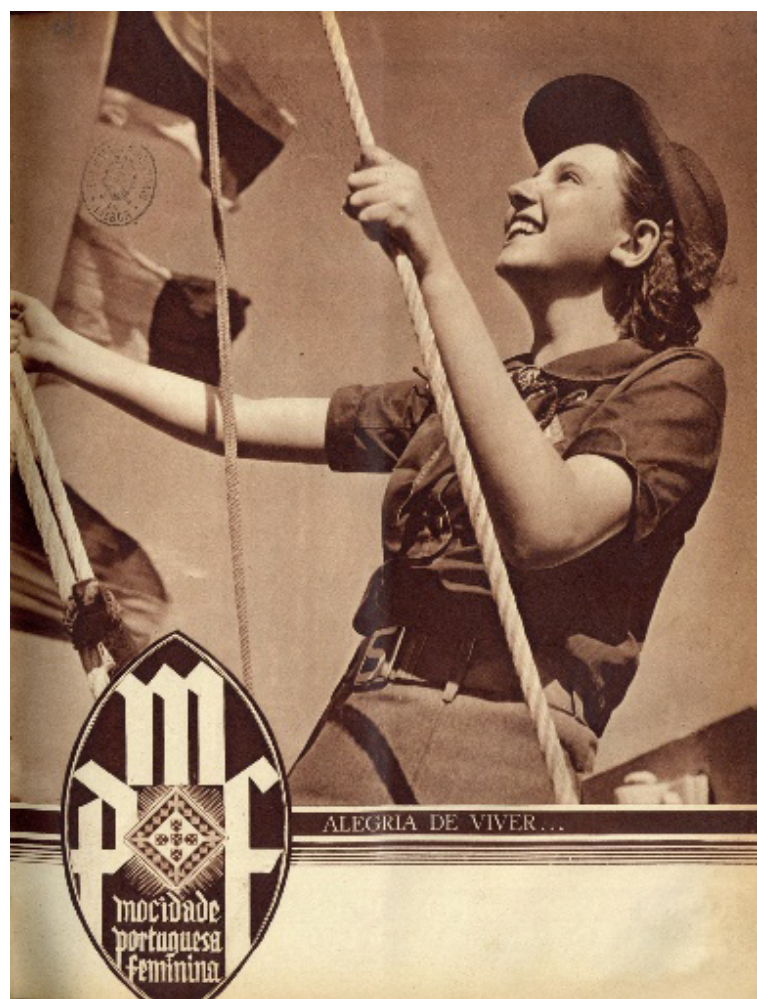

Fonte: Novais, Mário. Capa [fotografia impressa]. Boletim da Mocidade Portuguesa Feminina, n. ${ }^{4}$ (Agosto 1939).

Ao mesmo tempo, para aligeirar a componente paramilitar e miliciana, mais adequada ao universo masculino, fotografias como as de Walter San Payo ${ }^{17}$, mostram uma graciosidade juvenil enfatizada pelas posturas descontraidas (numa simulada ausência de pose para a câmara), pela leveza da indumentária veraneante, e pelo cândido contexto campestre e floral, capa do n. ${ }^{\circ}$ 75-76 (Jul./Ag. 1945), (Figura 4). ${ }^{18}$
Figura 4 - Fotografia de capa de Walter San Payo

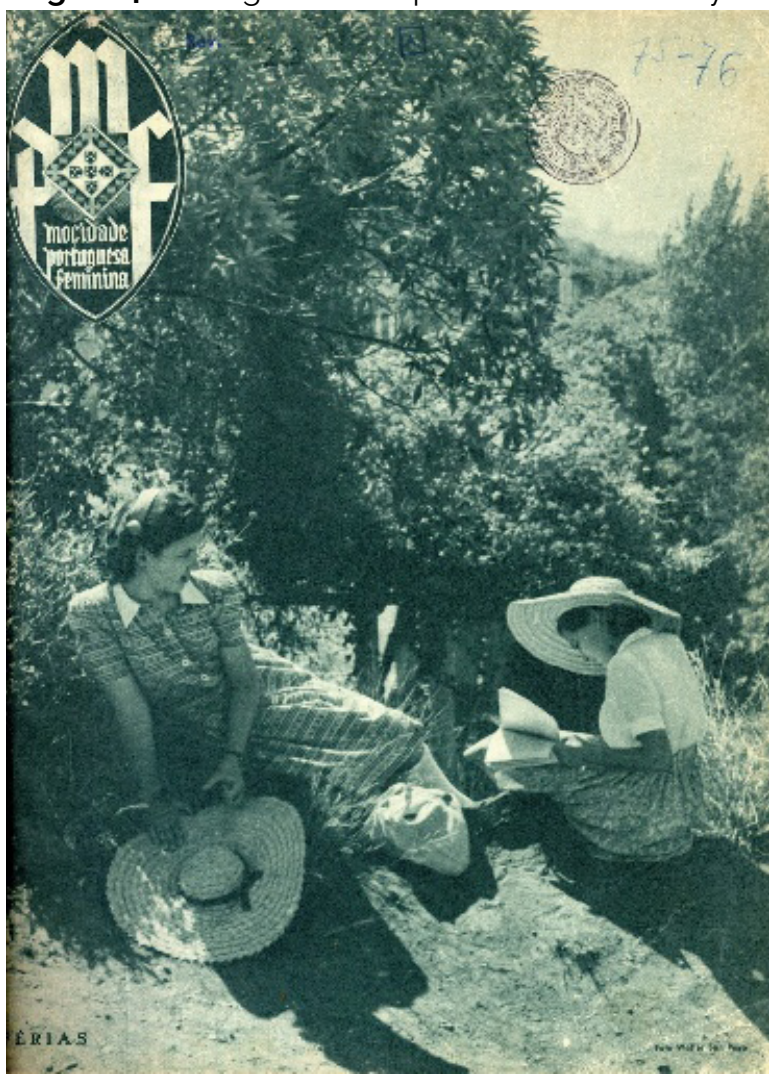

Fonte: San Payo, Walter. Capa [fotografia impressa]. Boletim da Mocidade Portuguesa Feminina, n. ${ }^{\circ}$ 75-76 (Jul./Agosto 1945).

\section{A ubiquidade do motivo floral e do cenário campestre}

Um dos principais elementos associados à feminilidade é a iconografia floral. Esta aparece em inúmeros arranjos de flores - autênticas naturezas-mortas esmeradamente compostas em estilizações de ressonância barroca -, encenados para a fotografia. ${ }^{19}$

Neste âmbito, a "fotografia de natureza" constitui uma das temáticas privilegiadas no Boletim, implicando um valor simbólico, tanto em ramos, n. ${ }^{\circ} 13$ (Maio 1940, contracapa) e n. ${ }^{\circ} 71$ (Março 1945. capa), como em ambientes que se convertem em panos de fundo cenográficos. Expediente explorado em inúmeras capas que marcam a chegada da Primavera, como no n. ${ }^{\circ} 11$ (Mar. 1940,

\footnotetext{
17 Filho do fotógrafo Manuel Alves de San Payo (1890-1974), autor das fotografias de teor pictorialista e de carácter religioso no Boletim. 18 Veja-se, igualmente, o número 53 (Set. 1943) e 78 (Out. 1945).

19 N. ${ }^{\circ} 13$ (Maio 1940, "Sumário"); n. ${ }^{\circ} 2$ (Dez. 1940, capa); n. ${ }^{\circ} 25$ (Maio de 1941, "Sumário"); n. ${ }^{\circ} 27$ (Jul. 1941, capa/parte inferior); n. ${ }^{2} 23$ (Mar. 1941, "Florinhas da rua... Florinhas dos salões?").
} 
(capa) ${ }^{20}$, sinalizando o "universal" nexo entre o simbolo da flor e o universo da feminilidade, com as prerrogativas que the estão associadas: passividade, beleza, pureza, fertilidade...

Para além do cenário da praia, que nesta época "ganha ascendente sobre as termas [...] sobretudo para as gerações mais novas" (VIEIRA, 1999, p. 108), as férias de verão têm sucessivamente como pano de fundo o ambiente campestre, n. ${ }^{\circ} 27$ (Jul. 1941, "As nossas férias"); n. 39 (Jul. 1942, "Férias"). Este cenário ganha particular fulgor na capa do n. ${ }^{\circ} 27$ (Jul. 1941), com evidentes influências vindas da estética da Alemanha Nazi. Uma jovem fardada com sorriso prazenteiro atravessa um campo de searas e de braços abertos afaga as espigas. Nesta fotografia convergem os papéis da condição feminina de mulher e mãe num cenário de abundância, como sinónimos de fertilidade (Figura 5). ${ }^{21}$

Figura 5 - Fotografia de capa de Foto Beleza em Julho 1941.

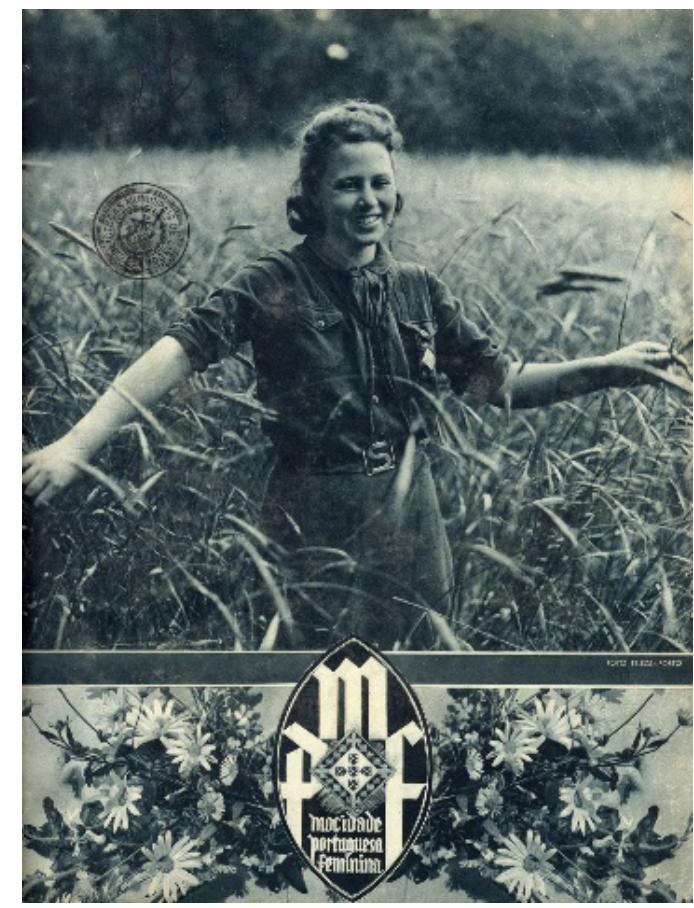

Fonte: Foto Beleza, Capa [fotografia impressa]. Boletim da Mocidade Portuguesa Feminina, n. ${ }^{\circ} 27$ (Jul. 1941).

Dentro do espírito da "recristianização" da nação, estas são sempre imagens pouco entusiasmadas com a modernização e urbanidade, que apesar de tudo se fazia sentir no país, resultado de uma ousada política de obras públicas (BRITES, 2017). Ainda que de forma pontual, a pertinência com que são evocados espaços capitais e legendários da cidade, o padrão figurativo da capital domina, n. ${ }^{\circ} 14$ (Jun. 1940, "Exposição do Mundo Português"). A Lisboa retratada é, assim, a dos monumentos, n. ${ }^{\circ} 21$ (Jan. 1941, "Portugal") e das praças ligadas ao Poder, n. ${ }^{\circ}$ 74 (Jun. 1945, "A manifestação da gratidão nacional a Carmona e Salazar"), encontrando aí o eco ideal dado pela tradição histórica como identificadora da cidade.

Mas é também sobretudo a Lisboa dos parques e dos jardins, n. ${ }^{\circ} 28$ (Ago. 1941, "O que nós queremos que as nossas raparigas sejam"), em contraste com qualquer ambiência mundana e cosmopolita. Excepcionando as docas com navios, n. ${ }^{\circ} 2$ (Jun. 1939 , "A viagem presidenciala África"), a dominante é uma imagem tradicionalista da cidade, como antítese e antídoto à voracidade dos modernismos (ALVES, 2013).

A presença a outras cidades constitui assim citações indirectas de viagens ou alusão aos grupos de Mocidade Feminina aí existentes, como sucede com Évora n. ${ }^{\circ} 87-88$ (Jul./Ago. 1946, "O passeio das graduadas"); Porto n. ${ }^{\circ} 22$ (Fev. 1941, "A MPF no Porto"); ou Viseu n. ${ }^{\circ} 41$ (Set. 1942, capa). Outras referências ligam-se particularmente a motivos de identidade nacional, como Guimarães, n. ${ }^{\circ} 14$ (Jun. 1940, "A fundação de Portugal").

Enquanto laboriosa construção, este discurso pretende assim contradizer e refutar o pais "real" do dia-a-dia em que as classes mais baixas vivem e que a jovem mulher burguesa de classe média e alta encontra quotidianamente no espaço público, n. ${ }^{\circ} 28$ (Ago. 1941, "Os que não têm férias"). Dá-se assim uma imposição fotográfica oficial encenada, subsidiária da ruralidade estilizada que a literatura e a pintura fixaram.

Num claro manifesto do folclorismo elegante, a fotografia participa insistentemente nesta recriação mítica de uma ruralidade essencial como quadro de vida, reinventando comportamentos, danças e indumentárias. É neste contexto que as

20 E nos números 36 (Abr. 1942, capa) e 60 (Abr. 1944, capa).

${ }_{21}$ Esta temática encontra-se plasmada em muitos outros números, n. ${ }^{\circ} 47$ (Mar. 1943, capa); n. ${ }^{\circ} 53$ (Set. 1943, capa); n. 60 (Abr. 1944. capa); n. ${ }^{\circ} 75 / 76$ (Jul./Ago. 1945, capa); n. ${ }^{\circ} 78$ (Out. 1945, capa); n. ${ }^{\circ} 38$ (Jun. 1942, "Campismo"). 
"tradições populares" aparecem como uma oferta de turismo etnográfico, mostrando as poses encenadas e orgulhosas de moças que envergam impecáveis trajes regionais ${ }^{22}$. Nesta teatralização dos tipos e actividades populares, a fotografia continua a servir propósitos de estilização criando uma linguagem do artificial que perdurava, para demonstrar que o país permanecia intacto.

Figura 6 - Fotografias de Pires de Lima e Scuze

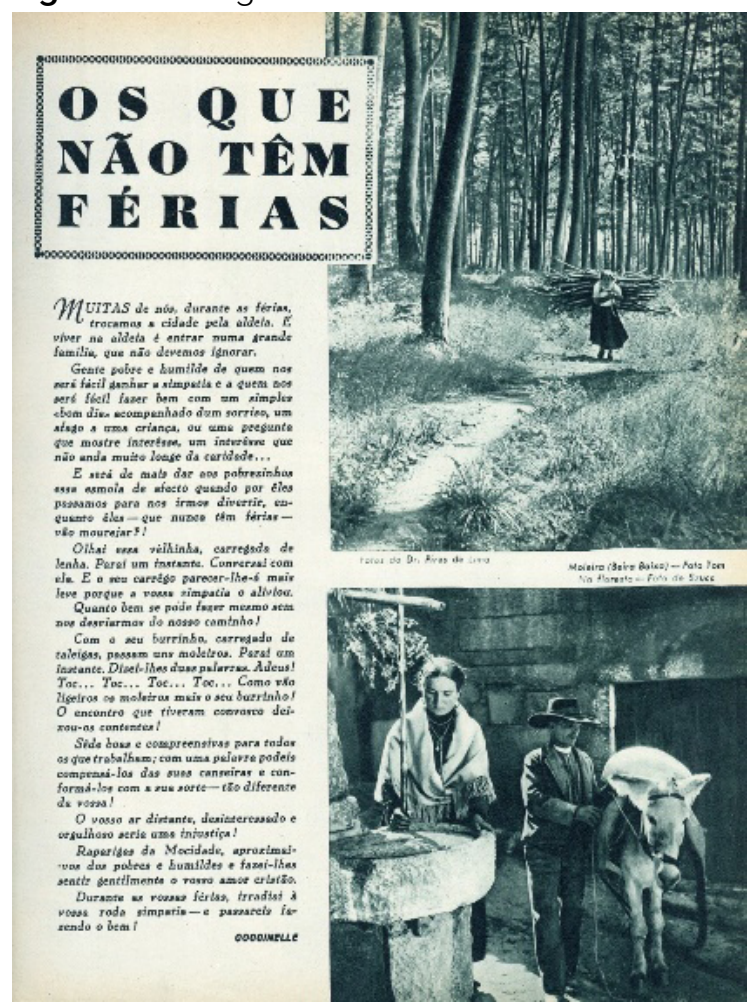

Fonte: Lima, Pires de (cima) e Scuze (baixo). "Os que não têm férias" [fotografia impressa]. Boletim da Mocidade Portuguesa Feminina, n. 28 (Agosto 1941).

Para temperar este ímpeto pitoresco, destinado a romancear o lado duro e terreno do seu quotidiano, algumas imagens "reais" do país e dos seus habitantes afastam-se por vezes deste pendor naturalista/pictoralista, assumindo um carácter de realismo documental, ao captar situações de carência social, usadas no Boletim para enfatizar a rudeza do trabalho do campo. São exemplo as que figuram no artigo "Os que não têm férias", n. ${ }^{\circ}$
28 (Ago. 1941), exortando a "caridade" em forma de "esmola de afecto", (Figura 6). Uma velhinha carregada de lenha às costas (fotografia de Pires de Lima) e dois moleiros "mais o seu burrinho" (fotografia de Scuze), compõem um registo mais próximo deste carácter "humanista", no qual se inserem igualmente as fotografias de José Martins Barata, de Pescadores na praia da Nazaré, puxando arduamente as suas embarcações para terra, n. 29 (Set. 1941, "Pescadores"); ou a devocional fotografia de Cottinelli Telmo retratando um "Menino Jesus do Povo", n. ${ }^{\circ} 44$ (Dez. 1942).

Comportando uma certa visão resignada do povo português, estes tipos humanos personificam tanto o mito da pobreza honrada, atestando a conformidade de cada um com o seu destino, como o mito da ordem corporativa, expressão de uma hierarquização social e harmoniosamente estabelecida.

\section{Uma triade de papéis: mãe, esposa e cuidadora do lar}

Para além das componentes religiosa e nacionalista, uma terceira função do Boletim correspondea um designio mais prático e utilitário quando entram em jogo os papéis de esposa e de mãe. Nesse sentido, proliferam imagens de berços, ${ }^{23}$ assim como retratos de meninas com bonecas ou peluches ao colo, exercendo precocemente o papel materno. ${ }^{24}$

A convicção de que a "domesticidade"25 é condição da mulher, ou seja, inerente à sua própria natureza, explica o número elevado de fotografias dedicadas ao lar. O investimento não se dá tanto ao nivel do conforto, mas em termos de "asseio e ordem", como "factores de beleza"26. O Boletim reflecte de forma directa essa expansão da fotografia ao nivel dos cuidados com a aparência e com os progressos da higiene, exortando que a sala obedecesse aos requisitos da boa exposição à luz e ao ar, n. ${ }^{\circ} 2$ (Jun. 1939, crónica "O Lar - A habitação: Arejamento da casa"). Tudo está devidamente limpo e arrumado, à parte dos livros colocados na mesa,

\footnotetext{
$22 \quad$ N. ${ }^{\circ} 23$ (Mar. 1941, "Uma festa no Cadaval"); n. ${ }^{\circ} 83$ (Mar. 1946, "A nossa festa").

N. ${ }^{\circ} 22$ (Fev. 1941, "A M.P.F. no Porto"); n. ${ }^{\circ} 46$ (Fev. 1943, "Berços e Enxovais")

24 N. ${ }^{\circ} 18$ (Out. 1940, "Obrigada, meu Deus!"); n. 26 (Jun. 1941) e n. 35 (Fev. 1942)

25 Para cumprir o papel de dona-de-casa, uma série de trabalhos manuais, que envolviam rendas, bordados, costura e afins, são recorrentes. A sua importância espelha-se tanto na capa, n. ${ }^{\circ} 10$ (Fev. 1940); n. 46 (Fev. 1943), como ilustrando extensos artigos dedicados a essa temática, n. ${ }^{\circ} 2$ (Jun. 1939 "Primeiro Salão Estética da MP); n. ${ }^{\circ} 11$ (Mar. 1940, "Berços e Enxovais"); n. 62 (Jun. 1944 "VII Salão de Educação estética"). $26 \quad$ N. ${ }^{\circ} 83$ (Mar. 1946)
} 
sinal de leitura e de alguma avidez de informação e cultura, n. ${ }^{0} 29$ (Set. 1941, "5. ${ }^{\circ}$ Elegantes"), (Figura 7) ${ }^{27}$, estando implícito que as mulheres das classes altas,

[...] deveriam possuir um mínimo de noções que the permitissem, por um lado, gerir um 'lar', pela via indirecta das 'criadas', e um mínimo de cultura geral e de consciência social que thes permitissem, por outro lado, 'acompanhar' o marido, praticar a caridade e 'lidar' com as mulheres de outras classes sociais (PIMENTEL, 2000, p. 403).

Figura 7 - Fotografias de Foto Beleza

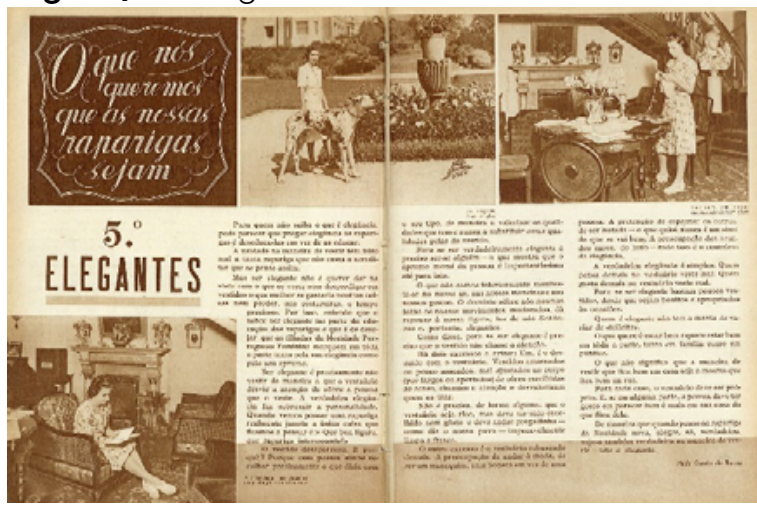

Fonte: Foto Beleza. " 5 Elegantes" [fotografia impressa]. Boletim da Mocidade Portuguesa Feminina, n. 29 (Set. 1941).

São imagens meramente indicativas que revelam uma certa dificuldade de acerto entre a ilustração e a fotografia e por vezes desenquadradas do contexto habitacional português. Em matéria de decoração de interiores, acertado com os manuais escolares, o Boletim exprime uma ideologia retrógrada comparado com as revistas de larga divulgação como a llustração Portuguesa, a Voga ou a Eva. Esse conservadorismo vem atestado num artigo intitulado "O Lar", n. ${ }^{\circ} 47$ (Mar. 1943), no qual figuram fotografias do interior da Pousada de Elvas (organizada pelo SPN no quadro da sua campanha de Bom Gosto), em jeito de recomendação pela "sua distinção e bom gosto".

No que concerne ao "locus" do lar, seria impossivel situar estes cenários domésticos no casario das vielas sujas e degradadas das freguesias periféricas, onde amontoava o operariado; muito menos na dos meios rurais, onde se desconhecia o conforto. Espelho invertido, ${ }^{28}$ porque a realidade que as fotografias nos devolvem é, por contraste, esta espécie de "paraíso", de utopia ou imagem prospectiva que constitui, no entanto, um privilégio reservado a uma pequena elite, impensável à época nas habitações populares.

Encontramos uma excepção no cliché de Augusto Luciano Alves, com a legenda "Cozinha de Aldeia", publicado para ilustrar o artigo "O fogo, o lar e a mulher" da autoria de Agostinho de Campos, n 36 (Abr. 1942). Para reforçar esta homenagem feita ao papel ancestral da mulher como guardiã do fogo e do lar, a fotografia parece uma cândida pintura naturalista: idilica visão, filtrada pelos cânones oitocentistas, transmite a ideia de um caloroso conforto maternal.

\section{Indumentária e regras de aparência: a elegância discreta}

Com a chegada das férias de verão e da época balnear, o fato de banho vai constituir uma das maiores preocupações da MPF, reverberando a "moralização das praias", iniciada em 1930 pela OMEN e pelas organizações católicas femininas (PIMENTEL, 2000, p. 349). Em nome do pudor, várias imagens são reveladoras da austeridade e do moralismo ${ }^{29}$, em detrimento do impróprio maillot.

Daqui decorre uma estética puritana e tradicionalista, resistente às influências estrangeiras, situando a rapariga-tipo da MPF fora da engrenagem do individualismo e materialismo associados à época. Por isso, dentro desta lógica "conservadora", se encontra, a par da permeabilidade às influências da moda, a exortação às "verdadeiras rendas" e "vestidos de seda" que o artigo "Velhas Arcas", n. ${ }^{\circ} 89$ (Set. 1946) promove, através de imagens de senhoras redescobrindo antigas "reliquias" guardadas em arcas de familia.

Mas a moda entra no Boletim, promovendo a elegância ao nivel do vestuário ${ }^{30}$. Embora o Bo-

\footnotetext{
${ }_{27}$ Veja-se igualmente n. 7 (Nov. 1939, capa); n. ${ }^{18}$ (Out. 1940, "Um centro da MPF"); n. ${ }^{\circ}$ 75-76 (Jul./Ago. 1945, capa); n. ${ }^{\circ} 89$ (Set. 1946, capa) 28 "Na década de 20, devido ao rápido crescimento demográfico, à inflação e à falta de emprego, a situação social agravou-se. Aumentaram as pessoas sem lar, que improvisavam um lugar para passar a noite. Eram as 'larvas humanas' que tiveram uma vida e um nome. um passado e um lar' e que, agora, estavam à margem da sociedade" (CASCÃO, 2011, p. 40).

$29 \quad$ N. ${ }^{\circ} 3$ (Jun. 1939, "na praia do Estoril"); n. 28 (Ago. 1941, capa); n. ${ }^{\circ} 40$ (Ago. 1942, "escuta a voz do mar").

30 N. 9 (Jan. 1940, "Por onde andam os nossos chapéus?..."); n. 84 (Abr. 1946, "Modas"); n. 86 (Jun. 1946, "Modas para o Verão") e n. ${ }^{\circ} 89$ (Set. 1946, "Modas")
} 
letim tivesse a pretensão de se dirigir a todas as jovens portuguesas - "todas" elas pretensamente enquadradas na MPF - foi, de acordo com Irene Pimentel, as das classes sociais mais altas que se quis e conseguiu atingir, como se pode ver pelos principais defeitos que se propôs combater no seio delas: "a futilidade, o hedonismo, a vaidade e arrogância" (PIMENTEL, 2000).

Para combater a coquetterie, a capa n. ${ }^{\circ} 70$ (Fev. 1945) actualiza o tema da Vanitas da pintura histórica, ao substituir a figura do Eremita ou da Maria Madalena por uma boneca excessivamente enfeitada diante do espelho (Figura 8). Com a palavra "Vaidade" na legenda, a mensagem é óbvia: o excessivo culto da aparência é sinónimo de esvaziamento de "alma". Este tom moralista surge noutras imagens de mulheres esmeradamente arranjadas, apresentadas como contra-exemplo para dissuadir as raparigas a não "perder de tempo", n. ${ }^{\circ} 6$ (Out. 1939), por exemplo, com "o difícil penteado de caracolinhos", e "a despeito das invenções modernas", promovendo o acompanhamento da moda com a necessária moderação, simplicidade e sentido prático.

Figura 8 - Fotografia de capa de Gonçalves em Fevereiro 1945

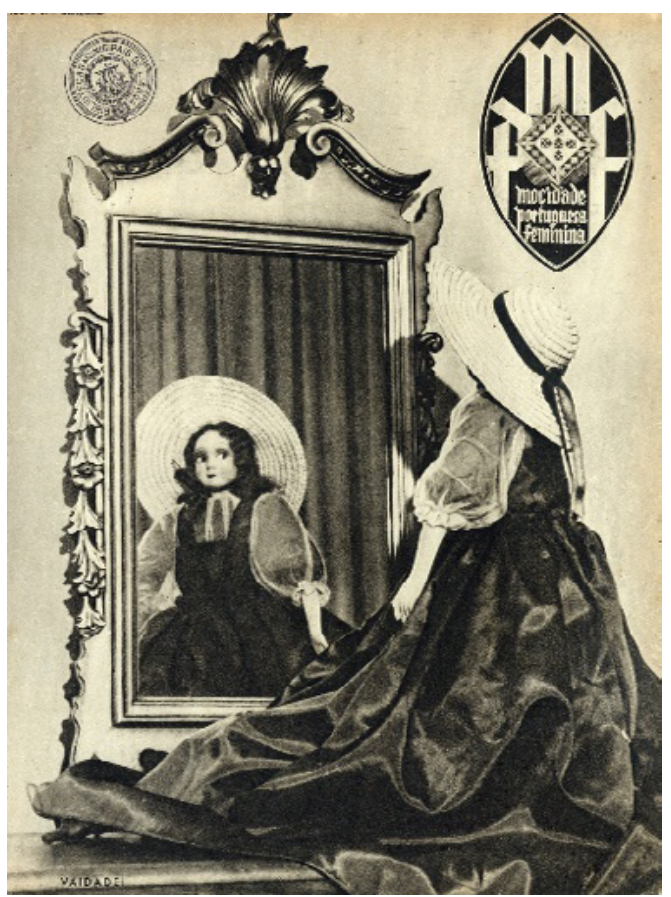

Fonte: Gonçalves. Capa [fotografia impressa]. Boletim da Mocidade Portuguesa Feminina, n. ${ }^{\circ} 70$ (Fev. 1945).
Por um lado, propunha-se, na rua, um vestuário modesto mas adaptado aos diversos meios sociais, pois nenhuma filiada devia usar roupa imprópria para a sua condição, n. ${ }^{\circ} 60$ (Abril de 1944. "Raparigas sérias II: A verdadeira elegância."); mas por outro, o uso das batas constituiu deliberadamente uma forma de encobrir diferenças sociais, homogeneizando os corpos e diluindo diferenças ao nivel da origem, n. ${ }^{\circ} 4$ (Ago. 1939, "Em Louvor às Batas Brancas"). Trata-se de uma tentativa de quebrar preconceitos e arrogância: "A missão do rico é curvar-se sobre o pobre que sofre e aliviá-lo", escreve Coccinelle em "Conselhos", n. ${ }^{\circ} 43$ (Nov. 1942). Complementando universalismo com elitismo (PIMENTEL, 2000, p. 243), estas imagens tentam atenuar a potencial conflitualidade entre o futuro escol feminino e as raparigas de outros meios mais modestos. Tal era feito através da caridade cristã e da ideologia corporativa que exortava um vestuário modesto adaptado aos diversos meios sociais. Tal aparece evidenciado numa série de imagens publicadas no n. ${ }^{\circ} 29$ (Set. 1941, "5. ${ }^{\circ}$ Elegantes"), em que as legendas reforçam o seu sentido exemplar. "Também em casa simplicidade e com gosto"; "ser elegante é ser simples"; "a intimidade não dispensa uma elegância discreta".

\section{Disciplina do corpo: desportos recreativos e ginástica formal}

A prática desportiva que figura no Boletim resume-se essencialmente a duas tipologias de imagens. A primeira, de carácter lúdico-recreativo, está associada a momentos de lazer e aos periodos de férias. Aqui inscrevem-se as fotografias alusivas a actividades desportivas que também tinham como alvo as raparigas de um estrato social médio e alto, incentivando a prática de modalidades elitistas, como equitação, sky, ténis etc. ${ }^{31}$ : Particularmente através do ski - um desporto "moderno em Portugal", n. ${ }^{\circ} 22$ (Fev 1941, artigo "prazeres da neve") -, as imagens revelam já um aburguesamento dos costumes, ou seja, uma certa permeabilidade a actividades cultivadas no estrangeiro, como positivo sinal de modernidade assumido pelo Boletim.

31 Equitação, n. ${ }^{\circ} 16$ (Ago. 1940); ski, n. ${ }^{\circ} 10$ (Fev. 1940, artigo “Neve"), nº 22 (Fev. 1941, capa e artigo “Prazeres da neve"); ténis, n. 77 (Set. 1945, capa). 
A outra tipologia é relativa aos exercícios praticados nas aulas do ensino oficial da ginástica. Neste ponto, importa lembrar que o Estado Novo criou fundamentações originais, particularmente eficazes na diferenciação educacional dos sexos, elaborando um discurso que vê a separação relativa ao universo dos homens como uma mais-valia para o sexo feminino. Daí o acautelar de corrupções que adviriam de desvios para-militaristas e físicos na formação da juventude feminina e a precaução em definir o carácter não miliciano da MPF e o género de desporto favorável às futuras esposas e mães. Nesse sentido, as fotografias mostram que estes exercicios de ginástica formal têm lugar sobretudo no interior dos próprios liceus ${ }^{32}$, atestando a declarada desconfiança do regime salazarista em relação ao culto do corpo e dos desportos "competitivos" e "exibicionistas" na Itália e Alemanha (PIMENTEL, 2001).

Por estas razões, as actividades físicas nunca são competitivas e públicas, mas antes exercícios que estimulam a "camaradagem e colaboração entre as alunas", onde o objectivo é manter o "equilibrio" e a "ordem".

Com o objectivo de mostrar a adopção do "sistema sueco" pelo ensino oficial, as seis imagens de Martinez Pozal, n. ${ }^{\circ} 40$ (Ago. 1942, "A orientação da ginástica dentro da M.P.F."), dão conta de corpos "correctos" e "harmonicamente" desenvolvidos, (Figura 9). Não obstante uma das imagens destacar a disciplinada "marcha em continência", a saudação romana feita de forma concertada em duas colunas de raparigas, o texto contraria-a, ou, pelo menos, ameniza-a, afastando-as da virilidade masculinizada ao descrever tais demonstrações como "números de ginástica", mediante os predicados da "leveza", da "arte" e da "poesia de movimento", n. ${ }^{\circ} 53$ (Set. 1943, "Notícias da M.P.F. Poesia de movimento...").
Figura 9 - Fotografias de Fernando Martínez Pozal

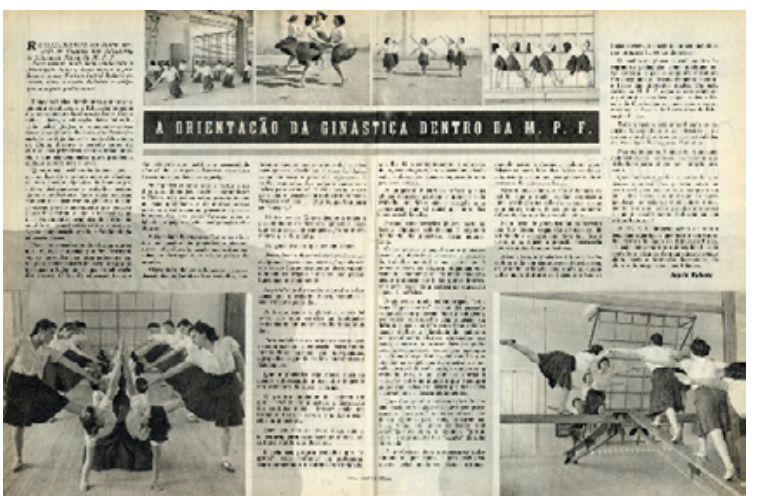

Fonte: Pozal, Fernando Martinez. "A orientação da ginástica dentro da M.P.F." [fotografia impressa]. Boletim da Mocidade Portuguesa Feminina, n. 40 (Agosto 1942).

\section{Modernidade e tradição: disputa, conciliação e correspondências entre forma e conteúdo}

É inequivoco que muitos dos arquétipos construidos em torno da imagem do novo "ideal de mulher" durante os anos 1930 e 1940 muito devem à acção dos periódicos ilustrados. A sua preponderância e disseminação, nas primeiras décadas do século $X X$, constituiu um fenómeno intimamente associado à ascensão do modernismo (SCHOLES; WULFMAN, 2010).

No caso português, as décadas de 30 e 40 são, desse modo, também periodos de afirmação duma nomenclatura oficial sob os compromissos daquilo que alguns autores designam de "modernidade contida" e que a politica do espirito impusera. A modernidade de António Ferro e de Leitão de Barros, plasmada no inovador O Notícias Ilustrado (1928-1935) e no "enérgico" Álbum Portugal 1934,33 trouxeram para primeiro plano o uso da imagem como incontornável suporte de propaganda.

No Boletim a máxima expressão desse modernismo oficial - enquanto programa estético-político - ficou a cargo de um só autor, Mário Novais. De qualquer modo, a relação entre exploração formal e exaltação nacionalista desenvolvidas por este autor, acabam remetidas para os primeiros

\footnotetext{
32 N. 24 (Abril 1941, "A MPF no Algarve"); n. ${ }^{\circ} 40$ (Ago. 1942, "A orientação da ginástica dentro da M.P.F."); n. 78 (Out. 1945, "Nomeações de Dirigentes. Porto").

33 Sobre o Album 1934, consultar o trabalho de Natasha Revez (2012).
} 
números desta publicação. O arrepio deste caminho se, por um lado, está relacionado com a perda do élan fascista com o fim da guerra; por outro, aponta para uma adaptação da publicação face ao novo contexto político com a derrota dos regimes autoritários do eixo.

Tal motivo justifica que, no cômputo geral, impere o documentalismo convencional, que ora pode estar relacionado com a iconografía sacra, ora com um naturalismo pictórico que, no caso português, se arrastou, academizado, pelos anos 1940 adentro. O vigor documental, exaltante e mobilizador da coreografia "parafascista", vai progressivamente cedendo lugar à ubiqua iconografia floral de um naturalismo tardio e apaziguador que casa bem com o culto da terra e o mundo rural, tido como berço das virtudes pátrias.

Em sintese, para a linguagem imagética do Boletim, contribuiram essencialmente duas vias antagónicas: por um lado, o desacerto e confusão estética entre propaganda e foto-reportagem através de uma identidade oscilante entre a representação fotográfica da realidade e o conceito de verdade (TAVARES, 2015, p. 4);34 por outro, a persistência da herança pictoralista dos amadores de Oitocentos, cujas regras de harmonia, belo e técnica tudo deviam a um eleito estilo naturalista copiado da pintura. Estas duas linguagens acabam por coabitar, de forma menos tensional do que complementar, na matriz dúplice desse discurso visual.

Não obstante a inegável imposição de uma ordem ideológica para a qual contou o peso da Censura, podemos afirmar que o convivio entre uma dualidade de opções estéticas - a despeito da fusão ou da sintese - reverbera de forma fiel o modo como o próprio Estado Novo soube manter, numa lógica inclusiva, um conjunto de forças conflituantes em equilibrio, por acolher no seu seio essas polaridades contraditórias sem nunca eliminar nenhuma, temperando impetos mais radicais, sejam estéticos ou políticos.

No que respeita à representação das cerimónias públicas de cariz nacionalista, é actuante o vigor documental e o modelo modernista oficializado de Mário Novais com os seus jogos geométricos e arrojo formal. Inúmeros retratos de filiadas exploram, nesse registo, através do close-up em contrapicado, o sensacionalismo do exacerbamento das emoções. Aqui só há espaço para o outro extremo: o da seriedade grave afecta à formalidade do porte quando, individualmente, as filiadas ladeiam estandartes com as altas insignias nacionais ou, colectivamente, integram formaturas em cerimónias solenes subordinadas à ideia de uma "coreografia mobilizadora e colectivadora" (PIMENTEL, 2001, p. 312).

Enquanto dispositivo de inculcação ideológica autoritária, o aparelho de educação nacional, do qual dependia a MPF, em certo sentido reabilita o desígnio original da propaganda - palavra derivada da Congregatio de Propaganda Fide (Congregação para a Propagação da Fé) - ao reactivar a iconografia tradicional na alta tarefa de instrução catequística. Daí que para a representação da santidade e da pureza feminina, a fotografia resgate influências múltiplas da tradição sacra. Também o culto da maternidade está impregnado de um simbolismo iconográfico devedor da pintura.

A preponderância de contextos de ruralidade, que vimos ser igualmente um arquétipo fundamental da iconografia oficial do Estado Novo, bifurca-se em dois registos complementares: um conotado com a folclorização de estereótipos nacionais - é o modelo de inspiração idilico-naturalista de tipos-humanos pitorescos; a outra, a do país "real" implicado na rudeza objectiva dos seus habitantes, dá-nos um "retrato humanista" de exaltação do trabalho rural, espelhando um "desequilibrio social emergente, ainda que mascarado por uma alusão bucólica harmonicamente construida" (MACHADO, 2017).

O predomínio da iconografia floral, transversal a todo o Boletim, enquanto motivo formal estilizado e decorativo, é invocador de um óbvio substrato simbólico, em virtude da sua "universal" relação com a feminilidade. Ainda que a "beleza" seja uma das

34 "The journalistic commissioned nature of photographic image production on which the New State founded these first publications characterized the formal nature of these images as both objective and real, a combination that was confused with the concept of truth and which efficiently and pragmatically served the ideological purpose that the regime was to make of such images for mass publicity" (TAVARES, 2015, p. 12). 
suas prerrogativas, no que diz respeito à aparência, observa-se um moralismo conservador que actua contra os perigos da "vaidade". Daqui decorre uma estética tradicionalista e recatada, no que respeita a indumentárias e adereços de moda, situando a rapariga-tipo da MPF num microcosmo onde os vislumbres de "modernismo" aparecem dissimulados, como que diluidos num cenário mais abrangente, onde tudo parece previamente considerado.

\section{Considerações finais}

Arrumando de forma pouco inventiva as tipologias e géneros firmados pela tradição visual, a dialéctica entre tradicionalismo e modernismo encontra-se bem patente no Boletim, embora o pêndulo se incline com mais predominância para o primeiro dos lados. Importa, no entanto, ver que estes dois campos não são estanques, antes transitórios e interdependentes. Tal como vimos, o salazarismo, através do discurso oficial, apodera-se não apenas das imagens dos camponeses e dos pescadores, fazendo deles "uma tipologia visual simbólica" (TAVARES, 2009), pois também no caso da mulher "ideal" vai (re) construi-la, vendê-la como "nova" a partir de alguns modelos "antigos" (da santa, da rainha, da dona-de-casa, da mãe extremosa), como projecto a difundir enquanto construção putativamente moderna de uma identidade feminina nacional.

Porém, e não obstante a fotografia reflectir ainda uma sociedade dominante reverente à tradição, facto que prolonga alguma passividade e estagnação do próprio meio, a verdade é que ela se torna irremediavelmente também no meio privilegiado para promover algum aburguesamento de costumes. A prática de novos desportos, a actualidade das modas, a exortação da leitura, as idas à praia, as visitas a museus, os progressos das práticas de asseio doméstico, entre outros, testemunham uma abertura em linha com as classes sociais a que se dirigiam.

Nesse sentido, a imagem da mulher veiculada pelo Boletim não pode ser classificada simplesmente como "nova" ou "antiga". Não se excluindo mutuamente, trata-se antes do resultado não de uma negação, mas de uma negociação que torna possivel a articulação de elementos antagonistas ou contraditórios (BHABHA, 1994, p. 25), que, no quadro que define o Estado Novo, é sempre feita em nome dos consensos e do equilibrio entre forças diversas.

Desse modo, longe de ser intrinsecamente anti-moderno, podemos afirmar que o Estado Novo apenas rejeita os elementos alegadamente degenerativos da modernidade 35 no seu desígnio de construir uma "nova mulher", representando antes, e também nesse domínio, um modernismo alternativo ao invés de o rejeitar. Noutras palavras, a fotografia que, neste âmbito, foi posta ao seu serviço, assume-se como um dos mais poderosos dispositivos para reinventar o presente e imaginar futuros.

\section{Referências}

ACCIAIUOLI, Margarida. Exposições do Estado Novo 1934-1940. Lisboa: Livros Horizonte, 1998.

ACCIAIUOLI, Margarida. A Vertigem da Palavra: Retórica, Política e Propaganda no Estado Novo. Lisboa: Bizâncio, 2013.

ALVES, Vera. Arte popular e nação no Estado Novo: A política folclorista do Secretariado da Propaganda Nacional. Lisboa: Imprensa de Ciências Sociais, 2013.

ANDRÉ, Paula. Arquitectura moderna e portuguesa: Lisboa 1938-1948. 2010. Tese (Doutorado em Arquitectura e Urbanismo) - ISCTE-IUL, Lisboa, 2010.

ANTLIFF, Mark Fascism, modernism, and modernity. Art Bulletin, Is. l.], v. 84, n. 1, p. 148-169, mar. 2002. Disponivel em: https://www.jstor.org/stable/3177257. Acesso em: 1 abr. 2018. https://doi.org/10.2307/3177257.

BHABHA, Homi K. The Location of Culture. Londres: Routledge, 1994.

BARRON, Stephanie. Modern Art and Politics in Prewar Germany. In: BARRON, Stephanie (ed.). Degenerate Art: The Fate of the Avant-Garde in Nazi Germany. Los Angeles: Los Angeles County Museum of Art, 1991. p. 09-23.

BELKNAPP, Geoffrey. From Photograph Authentic Science and the Periodical Press, 1870-1890. London: Bloomsbery Academic, 2016

BOLETIM da Mocidade Portuguesa Feminina, n.1-n.96, maio 1949/abr. 1947.

BRITES, Joana. Estado Novo, arquitetura e «renascimento nacional. Risco: Revista de Pesquisa em Arquitetura e Urbanismo, [s. l.], v. 15, n. 1, p. 100-113, 2017. Disponivel em: http://www.revistas.usp.br/risco/article/view/131640. Acesso em: 1 abr. 2018. https://doi. org/10.11606/issn.1984-4506.v15i1p100-113. 
BRITES, Joana. Is there an Ideologically-Biased Broadening of the Concept of Modern Architecture? Questioning the Limits of Postmodernism's Inclusivism and Testing a Further Expansion. RIHA Journal, [s. l.], 0133, 15 jul. 2016.

CABRAL, Manuel Villaverde. A Estética do Nacionalismo Modernismo literário e autoritarismo político em Portugal no início do século XX. Novos estudos -Cebrap, São Paulo, n. 98, mar. 2014. https://doi.org/10.1590/ S0101-33002014000100006.

CALINESCU, Matei (1986), As Cinco Faces da Modernidade. Lisboa: Veja, 1999.

CASCÃO, Rui. Modos de Habitar. In: VAQUINHAS, Irene (coord.). História da Vida Privada em Portugal (A Época Contemporânea). Lisboa: Círculo de Leitores, 2011. v. 3. p. 22-54.

COVA, Anne; PINTO, António Costa. O Salazarismo e as mulheres: uma abordagem comparativa. Lisboa: Edições Cosmos, 1997

DE DUVE, Thierry. Echoes of the Readymade. Critique of Pure Modernism. In: BUSHIER, Martha; NIXON, Mignon. The Duchamp. Cambridge: Mit-Press, 1996. p. 93-127.

FERREIRA, Isabel Alves. Mocidade Portuguesa Feminina. Revista de História das Ideias, [s. l.], n. 16, p.193-233, 1994. https://doi.org/10.14195/2183-8925_16_7.

FERNÁNDEZ, Horacio. Fotografia Pública: Photography in Print 1919-1939. Madrid: Museo Nacional Centro de Arte Reina Sofia: Aldeasa, 2000

FOTO BELEZA. Capa [fotografia impressa]. Boletim da Mocidade Portuguesa Feminina, [s. l.], n. 27, jul. 1941.

FOTO BELEZA. $5^{\circ}$ Elegantes [fotografia impressa]. Boletim da Mocidade Portuguesa Feminina, [s. l.], n. 29, set. 1941.

FREIRE, Isabel. Amor e Sexo no Tempo de Salazar. Lisboa: Esfera dos Livros, 2010.

GARCIA, José Luis Lima. A Agéncia Geral das Colónias/ Ultramar e a Propaganda do Estado Novo (1932-1974). In: RODRIGUES, Alberto Pena; PAULO, Heloísa (coord.). A Cultura do Poder: A Propaganda no Estados Autoritários. Coimbra: Imprensa da Universidade de Coimbra, 2016.

GENTILE, Emilio. Qu'Est - Ce que Le Fascisme? Histoire et Interpretation? Paris: Gallimard, 2004.

GONÇALVES. Capa [fotografia impressa]. Boletim da Mocidade Portuguesa Feminina, [s. l.], n. 70, fev. 1945).

GREENBERG, Clement. "Modernisme Painting" (1960). In: GREENBERG, Clement. Art and Culture: critical essays. Boston: Beacon Press, 1989. p. 754-760. [1. ${ }^{a}$ edição em 1961]

GRIFFIN, Roger. Modernism and Fascism: The Sense of a Begining Under Mussolini and Hitler. London/New York: Palgrave Macmillan, 2007.

GRIFFIN, Roger. Modernity, Modernism, and Fascism: A "Mazeway Resynthesis". Modernism/Modernity, [s. L.], v. 15, n. 1, p. 09-24, 2008. https://doi.org/10.1353/mod.2008.0011.

HERF, Jeffrey. Reactionary Modernism: Technology, Culture and Politics in Weimar and the Third Reich. Cambridge: Cambridge University Press, 1984. https:// doi.org/10.1017/CBO9780511583988.
HOBSBAWM, Eric; RANGER, Terence (ed.). The Invention of Tradition. Cambridge: Cambridge University Press, 1983.

KRAUSS, Rosalind. "Impressionism". Partisan Review, New York, v. 42, p. 63-73, 1974.

KUIN, Simon. Mocidade Portuguesa. In: ROSAS; Fernando; BRANDÃO, J. M. (coord.). Diccionário de História do Estado Novo. Lisboa: Círculo de Leitores, 1996. p. 607-608.

LEAL, Joana Cunha. An Introduction: Around Southern Modernisms. RIHA Journal, [s. l.], 0131, 15 jul. 2016. Disponivel em: www.riha-journal.org/articles/2016/ 0131-0140-special-issue-southern-modernisms/ o131-cunha-leal.

LEAL, Joana Cunha; SANTOS, Mariana Pinto. As "sete cabeças" do modernismo. In: CRESPO, Nuno (ed.). Arte critica política. Lisboa: Tinta da China, 2016. p. 93-111.

LEFAIVRE, Liane; TZONIS, Alexander. Critical Regionalism: Architecture and Identity in a Globalized World. Munich: [s.l.], 2003

LIMA, Pires de e SCUZE. "Os que não têm férias" [fotografia impressal. Boletim da Mocidade Portuguesa Feminina, [s.L.], n. 28, ago. 1941.

MACHADO, Ana Patrícia Milhanas. Para uma propaganda educacional: o registo fotográfico de Mário Novais em torno de uma visita da Mocidade Portuguesa Feminina ao Museu Nacional de Arte Antiga. Comunicação Pública, v. 12, n. 23, 2017. Disponivel em: https:// journals.openedition.org/cp/1912. Acesso em: $1^{\circ} \mathrm{abr}$. 2018. https://doi.org/10.4000/cp.1912.

MATARD-BONUCCI, Marie Anne. "L'homme nouveau entre dictature et totalitarisme (1922-1945)". Marie-Anne Matard-Bonucci et Pierre Milza, L'homme nouveau dans l'Europe fasciste (1922-1945). Entre dictature et totalitarisme. Paris: Fayard, 2004.

MASCARENHAS, João Mário; NEVES, Helena; CALADO, Maria (coord.). O Estado Novo e as Mulheres: O Género como Investimento Ideológico e de Mobilização. Lisboa: Câmara Municipal de Lisboa, 2001.

MELO, Daniel. Salazarismo e Cultura Popular (1933-1958). Lisboa: Instituto de Ciências Sociais, 2001.

MITTER, Partha. Decentering Modernism: Art History and Avant-Garde Art from the Periphery. The Art Bulletin, [s. l.], v. 90, n. 4, p. 531-548, dez. 2008. https://doi.org/ 10.1080/00043079.2008.10786408.

NOVAIS, Mário. Capa [fotografia impressa]. Boletim da Mocidade Portuguesa Feminina, n. 4, ago. 1939.

NOVAIS, Mário. Capa [fotografia impressa]. Boletim da Mocidade Portuguesa Feminina, n. 21, jan. 1941.

Ó, Jorge Ramos do. Os Anos de Ferro. O dispositivo cultural durante a "Política do Espirito" 1933-1949. Lisboa: Editorial Estampa, 1999

OFER, Inbal. A "New" Woman for a "New" Spain: The Sección Femenina de la Falange and the Image of the National Syndicalist Woman. European History Quarterly, [s. L.], v. 39, n. 4. p. 583-695, 2009. Disponivel em: http://journals. sagepub.com/doi/abs/10.1177/0265691409342657. https://doi.org/10.1177/0265691409342657. 
PAULO, João Carlos. Exposições Coloniais. In: ROSAS, Fernando; BRITO, J. M. Brandão (coord.). Diccionário de História do Estado Novo. Venda Nova: Bertrand, 1996. p. 327-329. v. 1.

PIMENTEL, Irene. Contributos para a História das Mulheres no Estado Novo. As Organizações Femininas do Estado Novo. A «Obra das Mães pela Educação Nacional» e a «Mocidade Portuguesa Feminina» (19361966). Tese (Mestrado em História dos Séculos XIX e XX) - FCSH-UNL, Lisboa,1996.

PIMENTEL, Irene. Mocidade Portuguesa Feminina. Lisboa: Esfera dos Livros, 2000.

PIMENTEL, Irene. A cada um o seu lugar. A política feminina do Estado Novo. Lisboa: Temas e Debates, 2011.

POMAR, Alexandre. "A fotogenia do Estado Novo": um capítulo esquecido da história da fotografia e do modernismo nacionais. Cartaz suplemento do Semanário Expresso, 28/02/1998.

POZAL, Fernando Martinez. "A orientação da ginástica dentro da M.P.F." [fotografia impressa]. Boletim da Mocidade Portuguesa Feminina, n. 40, ago. 1942.

REVEZ, Natasha F. M. P. Os Álbuns Portugal 1934 e Portugal 1940 - Dois retratos do país no Estado Novo. 2012. Dissertação (Mestrado em História da Arte) FCSH-UNL, Lisboa, 2012.

ROSAS, Fernando. O salazarismo e o homem novo: ensaio sobre o Estado Novo e a questão do totalitarismo. Análise Social, [s. l.], v. 35, n.157, p. 1031-1054, 2001.

SAN-PAYO. Capa [fotografia impressa]. Boletim da Mocidade Portuguesa Feminina, n. 32, dez. 1941.

SAN-PAYO, Walter. Capa [fotografia impressa]. Boletim da Mocidade Portuguesa Feminina, n. 75-76, jul./ago. 1945.

SCHOLES, Robert; WULFMAN, Clifford. Modernism in the Magazines - The Case of Visual Art. Modernism in the Magazines: An Introduction. New Haven: Yale University Press, 2010.

SERRA, Filomena. Introdução. Comunicação Pública lon-line], v. 12, n. 23, 2017. Disponivel em: http://journals. openedition.org/cp/1961. Acesso em: 16 jun. 2018. https://doi.org/10.4000/cp.1961.

TAVARES, Emilia. João Martins - Imagens de um tempo descritivo desolador. Porto: Mimesis, 2001.

TAVARES, Emilia. Batalha de Sombras. Vila Franca de Xira: Câmara Municipal de Vila Franca de Xira; Museu do Neo-Realismo, 2009.

TAVARES, Emilia. Retratos do Povo. In: NEVES, José (coord.). Como se Faz um Povo: Ensaios em História Contemporânea de Portugal. Lisboa: Edições Tinta da China, 2010. p. 401-414.

TAVARES, Emilia. History of Portuguese Photography 1900-1938. History of European Photography 1900-1930, [s. l.], p. 482-493, 2008.
TESSADORI, Pietro. O Homem Novo do fascismo italiano e do Estado Novo Português. Tese (Doutorado em História, Dinâmicas do Mundo Contemporâneo) - ISCTE - Instituto Universitário de Lisboa, Universidade de Lisboa, Universidade Católica Portuguesa e Universidade de Évora, Lisboa, 2014. Disponivel em: http://repositorio.ul.pt/bitstream/10451/15449/1/ ulsd069172_td_Pietro_Tessadori.pdf.

TRINDADE, Luis. O Estranho Caso do Nacionalismo Português. Lisboa: Instituto de Ciências Sociais, 2008.

TRINDADE, Luis. A forma de Almada: o século XX de Almada Negreiros. In: MUSEU CALOUSTE GULBENKIAN (org.). José de Almada Negreiros: uma maneira de ser moderno. Lisboa: Fundação Calouste Gulbenkian: Sistema Solar CRL (Documenta), 2017. p. 73-79.

UPTON, Dell. "Authentic' Anxieties". In: ALSAYYAD, Nezar (ed.). Consuming Tradition, Manufacturing Heritage. Global Norms and Urban Forms in the Age of Tourism. Londres: Routledge, 2001. P. 298-306.

VIEIRA, Joaquim. Crónica em Imagens 1930-1940. Portugal Século XX. Círculo de Leitores, 1999.

\section{Endereço para correspondência}

Bruno Sousa Marques e Israel Vindeirinho Guarda

Universidade NOVA de Lisboa

Instituto de História da Arte, Faculdade de Ciências Sociais e Humanas

Colégio Almada Negreiros, Campus de Campolide, sala 347

1070-312

Lisboa, Portugal 